\title{
Public and Individual Interests - Implications of the COVID-19 Pandemic
}

The authors provide a very useful starting point for initiating a discussion of the social and political as well as the technocratic implications of the coronavirus/ COVID-19 pandemic. In the following, I discuss the relationship between the pandemic's technological (or even technocratic) and its political dimension.

On the one hand, the COVID-19 pandemic seems to reinforce the divide between the two dimensions. Accordingly, the authors caution against a "technocratic mindset that appears divorced from and opposed to the sphere of politics and the discussion of public values" (Liu/Mitcham/Nordmann, thesis II). They even outline a growing perception of tensions "between the 'reasonable' people who exercise solidarity by acknowledging technical necessities and a somewhat reckless, rebellious populism which claims for itself the evacuated sphere of politics by invoking liberty and human rights" (Liu/Mitcham/Nordmann, thesis X).

On the other hand, in some ways the pandemic highlights the narrow limits of the very divide between technological/technocratic and political dimensions which it seems to reinforce at first glance. It rather exhibits the limits of the term 'technocracy' as it is often used. The term usually implies efficiency and - more importantly depoliticization. Technocratic/technological and political solutions to public challenges are two separate dimensions - or so it seems. Yet, the pandemic vividly draws attention to the fact that even technological solutions are designed to serve the public interest. The pandemic-related measures of prevention, containment and control are supposed to safeguard individuals and the population as a whole against the virus - sometimes even against individual wishes. This is the logic of the greater good: the public interest may outweigh individual interests.

It is this tension between public and (certain) individual interests that seems to trigger protests against COVID-19 measures. Here, I explicitly set aside conspiracy theorist motivations for such protests. I instead examine the conflict generated by those who feel their individual interests are being restricted, while they do not share or understand (or perhaps even believe in) the greater good. This may be the case because they value their own personal interests above anybody else's, but also because they are so deprived that they do not (perceive to) benefit from the public interest in the first place. Identifying their reasons is beyond the scope of this text. Instead, I focus on the relationship between technological/technocratic solutions, the public interest and individual interests. 
At some point in time, technological/technocratic solutions depend on some kind of legitimacy. At this point, they no longer represent depoliticized, purely technological questions; they also have to prove their output legitimacy - usually in the form of problem-solving capacities and efficiency. Yet, even the most technocratic versions of output legitimacy are connected to public interests. ${ }^{2}$ Efficiency is valid only within a certain context, and problem-solving capacities can only be evaluated in relation to specific problems that need to be defined. For both, the public interest constitutes an implicit or explicit point of reference. The pandemic makes this point very clear. If scientists are elevated to the position of "authorities" (Liu/Mitcham/ Nordmann, thesis VI), their authority is necessarily constituted through legitimacy via their contribution to the public interest. ${ }^{3}$ Therefore, the political dimension (which is concerned with the organization and regulation of public interests) is always inherent to technological and technocratic solutions.

Yet, speaking about the public interest raises the question as to who defines (which) interests as public. Who is included - and who excluded - from deliberating public interests? Answering these questions involves the democratic concept of input legitimacy, which is based on the participation and representation of citizens as well as their preferences, interests and individual wishes. ${ }^{4}$

Through the lens of input legitimacy and output legitimacy, the pandemic is neither exceptional nor different from common constellations of governance and government. Rather, it amplifies a tension that is inherent to all democracies and to political regimes that rely on some kind of legitimacy and recognition (as opposed to pure force): the continuous and infusible tension between public and individual interests, between input and output legitimacy. ${ }^{5}$ This tension opens the "black box of Sachzwang or technical exigency" (Liu/Mitcham/Nordmann, intro).

This diagnosis does not provide the COVID-19 pandemic with a ready solution. But it helps frame the challenges that come with it in more familiar terms. At least with regard to the pandemic's political and social dimensions, we can build on the

2 Jens Steffek: "The output legitimacy of international organizations and the global public interest," International Theory 7/2 (2015), pp. 263-293. Fritz W. Scharpf: "Problem-solving effectiveness and democratic accountability in the EU," Max-Planck-Institut für Gesellschaftsforschung Working Paper 3/1 (2003).

3 Janne Mende: "Business authority in global governance: Beyond public and private," WZB Berlin Social Science Center Discussion Paper, SP IV 2020-103 (2020). https://www.econstor.eu/h andle/10419/218731. A. Claire Cutler, Virginia Haufler, and Tony Porter, eds., Private authority and international affairs, Albany: State New York UP 1999.

4 Scharpf: "Problem-solving effectiveness".

5 See Tanja Brühl and Volker Rittberger: "From international to global governance. Actors, collective decision-making, and the United Nations in the world of the twenty-first century," in: Rittberger and Volker, eds., Global governance and the United Nations system, Tokyo, New York: United Nations UP 2001, pp. 1-47. Vivien A. Schmidt: "Democracy and legitimacy in the European Union revisited. Input, output and throughput," KFG The Transformative Power of Europe Working Paper 21 (2010). 
experience of political thought and practice. This does not hinder us from developing new pathways; quite the contrary. Against this background, I suggest three points of dealing with the pandemic's political and social dimensions.

First, the apparent dichotomy between technological/technocratic and political solutions must be overcome - yet not simply be dissolved. Rather, they rely on each other: technological expertise is grounded in political and social legitimacy as much as political solutions depend on technological expertise. If technological and technocratic solutions are not assumed to be apolitical, their political implications and effects can be addressed and discussed more clearly.

Second, describing the political and social dimensions of the pandemic requires reframing the apparent dichotomy between the rational belief in COVID-19 measures on the one hand, and the irrational disapproval of those measures on the other. Doing so enables dialogue between both sides to prevent them from drifting further apart. (Again, this does not refer to radical and extremist movements.) It also safeguards against the assumption that the party of "rebellious populism" dominates the "sphere of politics by invoking human rights and liberty" (Liu/Mitcham/Nordmann, thesis X). Rather, emphasizing the political dimension of technological, technocratic and rational solutions helps reclaim these points of reference. Human rights as a point of reference in particular create a basis for highlighting the connection between public and individual interests. Human rights also contribute to producing this connection in the first place in those cases, in which the reference to public interest is exploited to repress individual interests up to a point that violates human rights. Human rights even provide a point of reference for societies or governments that do not adhere to democratic values. All United Nations member states are obliged to respect, protect and ensure the fulfillment of human rights. ${ }^{6}$

Third, no viable solution to the pandemic can simply disregard individual interests in favor of the public interest, or vice versa. Rather, the tension between public and individual interests (between input and output legitimacy) must be upheld in order to balance and reconcile the two - ways that disregard neither side. Protecting the public interest during the pandemic may and does entail a necessary restriction of individual interests. This also protects certain individual interests (e.g. health) against others (e.g. not wearing face masks or meeting friends).

At the same time, defining and protecting public interests must be a matter of broad deliberation that includes a plurality of individual interests and voices. There are various (sometimes difficult) measures to achieve this. These may include a high degree of transparency regarding the development of COVID-19 measures and decisions (which also helps communicate the trial and error associated with new challenges). Such measures urgently include strong local processes of dialogue, inclusion

6 Janne Mende: "Are human rights western - and why does it matter? A perspective from international political theory," Journal of International Political Theory, 17/1 (2021), pp. 38-57. 
and cooperation which are able to strengthen a feeling of participation and responsibility among individuals (including for other parts of the society and for public interests). Measures also include international and global cooperation, ${ }^{7}$ thereby producing and setting an example for exactly the kind of solidarity and responsibility that individuals are asked to exhibit on a local level. Finally, measures must include taking the plurality of "the" public interest into account. Besides public health, this involves human rights, decent living conditions and gender equality, to name but just a few.

In sum, these measures help emphasize the intrinsic connection between technological, technocratic and expert legitimacy with public interests, and thus with politics. Individual interests do not simply outrank public ones, especially when it comes to the enjoyment of human rights for everyone (else). Nevertheless, they do count. The question of how they count is a challenge not only for the current pandemic, but for all governance constellations that are based on some kind of legitimacy.

\section{Steve Fuller}

\section{Prolegomena to the Political Science of Civil Libertarianism}

As COVID-19 reaches its first year as a global pandemic, much has been made of the awkward fit between genuine scientific uncertainty concerning the course of the virus and the need for effective political communication and policymaking. In practice, the world has become a living laboratory, with each nation's population serving as guinea pigs in rather different experiments based on largely the same science but applied under a variety of geographical, political and cultural conditions. Moreover, there are no agreed standards to make cross-national judgements about 'success' in handling the pandemic, though obviously the actions taken by governments have consequences for those outside of their formal jurisdictions. Indeed, every pronouncement by the World Health Organization that presumes such universal standards ends up striking one or more parts of the world as annoying backseat driving.

A useful albeit unexpected point of reference is the controversy over the meaning of Volk in Volkswirstschaft ('national economy') in early twentieth century Germany. On one side stood Werner Sombart and the Brothers Weber (Max and Alfred), who

7 Armin von Bogdandy and Pedro Villarreal: "The role of international law in vaccinating against COVID-19. Appraising the COVAX Initiative," Max Planck Institute for Comparative Public Law \& International Law Research Paper 46 (2020). Michael Ioannidis: "Between responsibility and solidarity. COVID-19 and the future of the European economic order," Heidelberg Journal of International Law/Zeitschrift für ausländisches öffentliches Recht und Völkerrecht 4 (2020). 